\title{
IMMUNOGENICITY ANALYSIS OF TRITERPENE GLYCOSIDE FROM HOLOTHURIA ATRA TO DETECTING FAS AND BCL-2 PROTEIN ON THE SP-C1 CELL OF TONGUE CARCINOMA
}

\section{UTMI ARMA ${ }^{1,2}$, MIEKE HEMIAWATI SATARI ${ }^{3}$, SYAFRUDDIN ILYAS ${ }^{4}$, DIAN HANDAYANI ${ }^{5}$, AMETA PRIMASARI ${ }^{6}$, NILA KASUMA $^{7}$, SUPRIATNO ${ }^{8}$, BASRI A GANI ${ }^{9}$}

\begin{abstract}
${ }^{1}$ Doctoral Program, Dentistry Faculty, Universitas Sumatera Utara, Medan, Indonesia. ${ }^{2}$ Department of Oral Medicine, Dentistry Faculty, Universitas Baiturrahmah, Padang, Indonesia. ${ }^{3}$ Department of Microbiology, Dentistry Faculty, Universitas Padjajaran, Bandung, Indoensia. ${ }^{4}$ Department of Biology, Mathematics and Natural Sciences Faculty, Universitas Sumatera Utara, Medan, Indonesia.

${ }^{5}$ Department of Pharmacy, Pharmacy Faculty, Universitas Andalas, Padang, Indoensia. ${ }^{6}$ Department of Oral Biology, Dentistry Faculty, Universitas Sumatera Utara, Medan, Indonesia. ${ }^{7}$ Department of Oral Biology, Dentistry Faculty, Universitas Andalas, Padang, Indonesia. ${ }^{8,}$ Department of Oral Medicine, Dentistry Faculty, Universitas Gadjah Mada, Yogyakarta, Indonesia. ${ }^{9}$ Department of Oral Biology, Dentistry Faculty, Universitas Syiah Kuala, Banda Aceh, Indonesia. Email: basriunoe@unsyiah.ac.id
\end{abstract}

Received: 01 February 2018, Revised and Accepted: 08 March 2018

ABSTRACT

Objective: The objective of this study is to assess the role of triterpene glycoside of Holothuria atra to induce the Fas and Bcl-2-regulated apoptosis in Supri's Clone 1 (Sp-C1) cell of tongue carcinoma.

Methods: The triterpene glycoside of H. atra was isolated by high-performance liquid chromatography. The Sp-C1 cell of tongue carcinoma was cloned by Dulbecco's Modified Eagle Medium and cytotoxicity assay by 3-4-5-dimethylthiazol-2yl 2,5-diphenyltetrazolium bromide assay. Expression Fas and Bcl-2 protein were analysed by immunocytochemistry also apoptosis detected by double staining ethidium bromide acridine. The datum of studied was analyzed by one-way analysis of variance (ANOVA), significance $(\mathrm{p}<0.05)$, and strength correlation $(\mathrm{p}<0.001)$ with $\mathrm{R}=1$.

Results: The H. atra has triterpene glycoside, and in the dose of $4 \mathrm{mg} / \mathrm{ml}$, it has been cytotoxic activities on the Sp-C1 (p<0.05), mortality $80 \%$; inhibitory concentration $50\left(\mathrm{IC}_{50}\right)=0.6$ and anti-logarithm $=4$. In general, the concentration of $2.5 \mathrm{mg} / \mathrm{ml}$ of triterpene glycoside has triggered the expression of Fas protein (active, 71\%; moderate, 10\%; and no-active, 27\%), whereas the Bcl-2 protein (active, 59\%; moderate, 14\%; and no-active $27 \%$ ). Statistically, both expressions of protein were significant ( $\mathrm{p}<0.05)$. Triterpene glycoside caused the apoptosis of Sp-C1 cell (strong, $87 \%$, and moderate, $13 \%)$.

Conclusion: The triterpene glycoside has the properties of cytotoxicity, and apoptosis in the SP-C1 cell also could be triggering the expression of Fas and Bcl-2 proteins.

Keywords: Holothuria atra, Cytotoxic-apoptosis, Bcl-2 and Fas proteins, Supri's Clone 1 cell, Triterpene glycoside.

(C) 2018 The Authors. Published by Innovare Academic Sciences Pvt Ltd. This is an open access article under the CC BY license (http://creativecommons. org/licenses/by/4. 0/) DOI: http://dx.doi.org/10.22159/ajpcr.2018.v11i6.25065

\section{INTRODUCTION}

Ninety-five percent of head, neck, and mouth cancers are squamous cell carcinomas (SCC) [1]. The frequency of the oral cavity SCC reached the sixth of the 10 most advanced cancers around the world and tended to increase [2]. The tongue is an area of concern for the incidence of oral cavity occurrence. SCC of the tongue represents $25 \%-50 \%$ of the total number of oral cavity SCC [3].

SCC is treated with surgery, radiotherapy, and chemotherapy or in combination, but the 5-year survival rate is poor, about 50\% [4], and according to Zhang et al. [5], even with 30\% local and regional recurrence combination therapy, $25 \%$ metastasis, and $5 \%$ survival by $40 \%$. Therefore, the target of developing anticancer drugs is directed to the induction of apoptosis [6], derived from natural materials, and one of them is a sea cucumber [7].

The tumor was called a disorder physiologically of cell growth in the body [8]. This is as a result of an apoptotic failure that caused by unsuccess checkpoint in G0 phase of cell cycle $[9,10]$. Theoretically, Bcl2 and Fas proteins on Supri's Clone 1 (SP-C1) are being the target of chemotherapy of anti-tumor [11]. Bcl-2 engaged in intrinsic pathway, whereas the Fas protein in the extrinsic pathway [12].
The natural products have an important role in cancer therapy, and a substantial number of clinically-used chemicals are derived from plants or animal [13]. A number of active component of plant reported to adherence the cancer cell metastatic such as Arctium lappa L. [14]. Liu et al. [15] reported that the triterpene glycoside of monk fruit was inhibited cancer into the body. It has to suppress P53 protein and decreasing regulation of matrix metallopeptidases and phosphorylated extracellular signal-regulated kinases.

Seas cucumbers are marine invertebrates that produce the secondary metabolites which have unique structures and useful biological activities [16]. In Indonesia, there are many sea cucumbers, one of them is Holothuria atra, originating from the sea of Mentawai (West Sumatra) [17]. The isolation of sea cucumber is triterpene glycoside which is the main bioactive compound of sea cucumber, with the wide structure of biological activity such as antifungal, cytotoxic, hemolytic, immune-modulatory effect, and antitumor [18].

The research of triterpene glycoside $H$. atra as the anticancer was reported by Aminin et al. [19] as the anti-malignant tumor of animal model, such as the cytotoxicity assay and apoptotic assay. Therefore, the development of anticancer by inducing apoptosis is importantly a 
targeted therapy. The study of triterpene glycoside $H$. atra to detect the Bcl-2 and Fas protein has been not reported this far. In consequence, this research was reposted the role of triterpene glycoside $H$. atra to induce the Bcl-2 and Fas protein-regulated apoptosis in $\mathrm{Sp}-\mathrm{C} 1$ cell of tongue carcinoma.

\section{METHODS}

\section{Materials}

The research has approved with the ethical clearance No.730/TGL/ KEPK/FK USU-RSUP HAM/2016 issued by Faculty of Medicine, University of Sumatera Utara, Medan, Indonesia. The eight concentrations of triterpene glycoside of $H$. atra assayed on the $\mathrm{Sp}-\mathrm{C} 1$ cell related the immune-expression of Bcl-2 and Fas proteins, cytotoxicity assay, and apoptosis assay.

\section{Purification of triterpene glycoside of $\boldsymbol{H}$. atra}

Isolation and purification of triterpene glycoside were used the column chromatography method with silica gel phase G60 and thin-layer chromatography with silica gel GF256 and Sephadex LH20 column method with methanol solvent to obtain one spot. Qualitatively of triterpene glycoside was analyzed by high-performance liquid chromatography (also used to triterpenoid assay with added 50$100 \mathrm{mg} / \mathrm{ml}$ of triterpene glycoside in $0.5 \mathrm{ml}$ of glacial acetate acid and incubated $15 \mathrm{~min}$ in tubes, and then added strong sulfate acid $0.5 \mathrm{ml}$ ). Positive has triterpene glycoside emerged brownish-red and purple colors [20,21].

\section{Cytotoxicity assay}

Cytotoxicity assay of Sp-C1 cell of tongue carcinoma had been analyzed by 3-4-5-dimethylthiazol-2yl 2,5-diphenyltetrazolium bromide (MTT) assay [22]. Triterpene glycoside concentrations used to inhibitory concentration $50\left(\mathrm{IC}_{50}\right)$ as the standard referred of the research model. $100 \mu \mathrm{l}$ triterpene glycoside in various concentration entered into the well-microplate 96 as well as Sp-C1 cancer cells. Microplates were incubated in $\mathrm{CO}_{2}$ incubators $24 \mathrm{~h}\left(5 \% \mathrm{CO}_{2}, 37^{\circ} \mathrm{C}, 98 \%\right.$ moisture $)$ and added each well plate $20 \mu \mathrm{l} 5 \mathrm{mg} / \mathrm{ml}$ MTT solution, a solution in plate $+100 \mu \mathrm{g}$ dimethyl sulfoxide to dissolve formazan crystals. Absorbance read by ELISA reader $520 \mathrm{~nm}$. The frequency of the percentage of SpCl1 mortality was adopted by Li et al. [23].

\section{Immunocytochemistry assay}

In this performance research methods, we were used the product of Abcam, Cambridge, MA, USA. The $80 \%$ confluent Sp-C1 cells did cell harvest and centrifuged at $1500 \mathrm{rpm} 5 \mathrm{~min}$, then the supernatant was removed, washed with phosphate-buffered saline (PBS), and fixed by methanol 5 min. Immunocytochemistry assay was adopted by Yuliani et al. [24]. The sample was blocked by hydrogen peroxidase during 15 min and washed with Phosftae buffer saline (PBS) 2 times, then added ultra $\mathrm{V}$ block and incubated $5 \mathrm{~min}$ at room temperature, washed with PBS. Identify Fas and Bcl-2 protein with adding the primary antibody (1:100), incubated $30 \mathrm{~min}$, rinsed with PBS 4 times, futhermore added biotinylated goat anti polyvalent and incubated $10 \mathrm{~min}$ at room temperature, washed with PBS 4 times, then, added streptavidinperoxidase also incubated $10 \mathrm{~min}$ at room temperature, rinsed with PBS respectively 4 times and added diaminobenzidine (DAB) plus chromogenic $10 \mu \mathrm{l}+500 \mathrm{ul}$ DAB and substrate, incubated $15 \mathrm{~min}$ and washed with PBS. The last was colored by Mayer's Hematoxylin $10 \mathrm{~min}$ and flushed by aquadest and dry, and the result was observed under a light microscope $\times 40$ [25].

\section{Apoptosis assay}

In this apoptosis assay, we used the product of Invitrogen Life Science Technologies, Foster City, CA, USA. Influence of triterpene glycoside of $H$. atra on the apoptosis activity of Sp-C1 was assayed by double acting ethidium bromide acridine orange method. The $80 \%$ confluent Sp-C1 cells harvested and centrifuged at $1500 \mathrm{rpm} 5 \mathrm{~min}$, then the supernatant was discarded. Pellet/precipitate added $1 \mathrm{ml}$ complete medium and reset it after doing the calculation with the counting chamber. Perform starvation with a media concentration containing
$0.5 \%$ fetal bovine serum (FBS). The cell is grown on 24 well-supplied slipcover plates, as many as 500,000 per $500 \mu$ lat each well and 24-h incubated in the $\mathrm{CO}_{2}$ incubator. The cell is grown on 24 well-supplied slipcover plates, as many as 500,000 per $500 \mu \mathrm{l}$ at each well and 24-h incubated in the $\mathrm{CO} 2$ incubator, then substituted 10\% FBS medium and treated cells with various concentrations, incubated $24 \mathrm{~h}$ in the CO2 incubator and the next day disposes of media and washed with PBS 2 times, covered by ethidium bromide acridine orange, observed in fluorescein microscope 40X [26,27].

\section{Statistical analyses}

The cytotoxicity, immunoexpressions of Bcl-2, Fas proteins, and apoptosis of the Sp-C1 cell of tongue carcinoma were analyzed by one-way analysis of variance (ANOVA) with a $\mathrm{p}<0.05$ and a correlation value of $\mathrm{p}<0.01$.

\section{RESULTS AND DISCUSSION}

\section{Triterpenoid analyses of $H$. atra}

The extracted total of $\mathrm{H}$. atra tested the compound of triterpene by the triterpenoid assay. Furthermore uses to evaluating the cytotoxicity, apoptosis, and expression of Bcl-2 and Fas protein [Fig. 1] [28]. Triterpene has the natural bioactive plant, animal, and fungus. It has anticancer, inflammatory effect, antioxidative, antiviral, antibacterial, and anti-fungal and also has the cytotoxically and chemoprotective activities on the neoplasm therapy [29]. Bishayee et al. [30] reported that triterpene takes a role in the apoptotic response of chemoprevention and tumor mammary cases.

\section{Cytotoxicity of triterpene glycoside}

The $\mathrm{IC}_{50}$ be a standard to measure the inhibition effect of triterpene glycoside with various doses $(\mathrm{mg} / \mathrm{ml})$. The minimum concentration $(4 \mu \mathrm{g} / \mathrm{ml})$ has a strong effect on cytotoxicity to Sp-C1 cell with mortality scores of $80 \%$, IC50=0.6, and anti-logarithm 4 , as well as mortality, is significant $(\mathrm{p}<0.05)$. These data are referenced to prescribe a concentration of the cytotoxicity assay of triterpene glycoside against Sp-C1 cell of tongue carcinoma (Table 1). The American National Cancer Institute suggested that the plant extract has the potential cytotoxic effect if they have $\mathrm{IC}_{50}<20 \mu \mathrm{g} / \mathrm{ml}$ [31]. Molyneux [32] declared that $\mathrm{IC}_{50}$ is the antioxidant concentration related to obstruct of $50 \%$ free radical activity and be avowed active in cytotoxic if the mortality of cell is achieved $80-100 \%$ (active), $50-79 \%$ (moderate), and $49 \%$ down is non-active [4].

The evaluation triterpene glycoside doses $0.5-4 \mu \mathrm{g} / \mathrm{ml}$ were assayed with minimal cytotoxic elicited an expression of Bcl-2 and Fas proteins also apoptosis on the Sp-C1 cell. Based on the cytotoxic assay, the doses of $2.5(\mu \mathrm{g} / \mathrm{ml})$ is the best standard evaluated of cytotoxic with anti-logarithm (2.197) and antioxidant (81\%). The scale of cytotoxicity are strong (0.049-0.199), moderate (0.222-0.699) and non-active

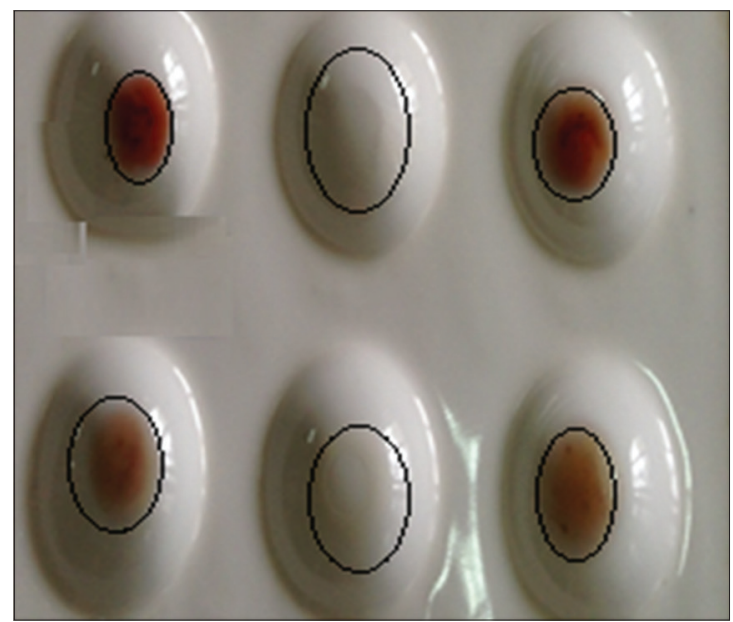

Fig. 1: The triterpene glycoside of Holothuria atra (circle of color) 

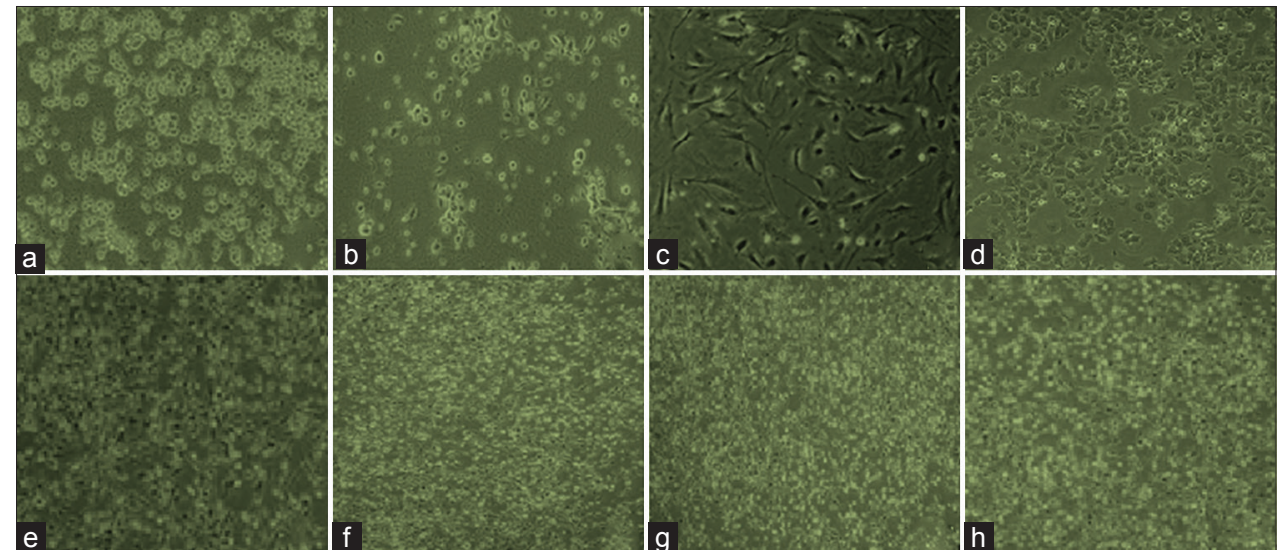

Fig. 2: Cytotoxicity of Supri's Clone 1 cells after $24 \mathrm{~h}$ treatment by triterpene glycoside of Holothuria atra in various doses (a) $0.5 \mu \mathrm{g} / \mathrm{ml}$, (b) $1 \mu \mathrm{g} / \mathrm{ml}$, (c) $1.5 \mu \mathrm{g} / \mathrm{ml}$, (d) $2 \mu \mathrm{g} / \mathrm{ml}$, (e) $2.5 \mu \mathrm{g} / \mathrm{ml}$, (f) $3 \mu \mathrm{g} / \mathrm{ml}$, (g) $3.5 \mu \mathrm{g} / \mathrm{ml}$, and (h) $4 \mu \mathrm{g} / \mathrm{ml}$. All images are magnified at ×40 (a-d) and $\times 10(e-h)$. The images are representative of at least five such fields of view per sample and three independent trials

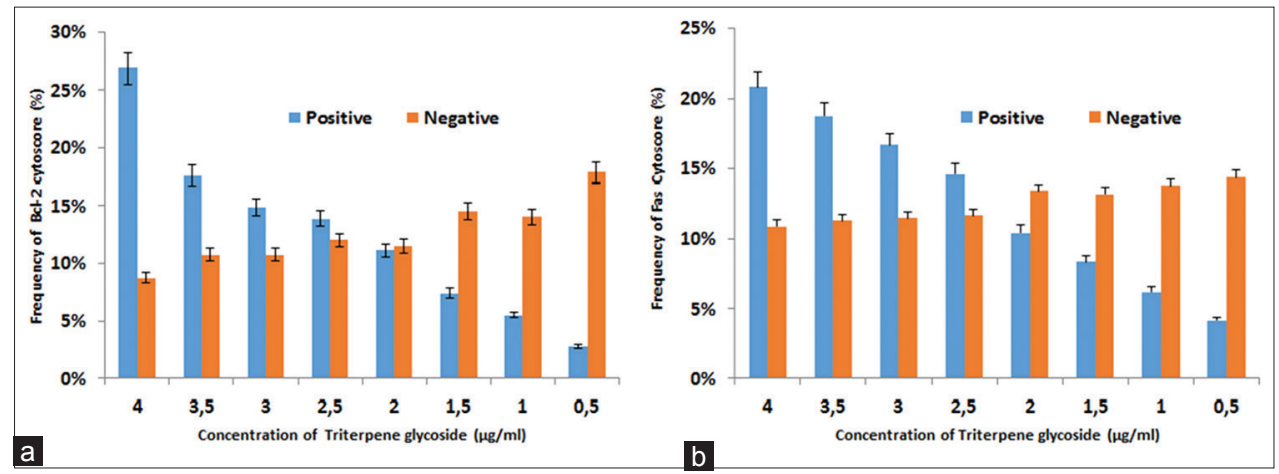

Fig. 3: Expression of Bcl-2 and Fas protein of Supri's-Clone 1 cell after sensitized by triterpene glycoside Holothuria atra (a) expression of the Bcl-2 protein and (b) expression of Fas protein

(0.745>). Fajarningsih et al. [33] explained the $\mathrm{IC}_{50}$ triterpene glycoside $0.239 \mu \mathrm{g} / \mathrm{ml}$ be included strong to adherent the development of cancer cells. The cytotoxic effect of triterpene glycoside on the Sp-C1 cell is shown in Fig. 2.

Our research has been in line with the study of Jangwan and Singh [34], and the triterpene extracted from Randia dumetorum Lamk was shown over cytotoxic effect $\left(\mathrm{IC}_{50}=\right.$ antilog $\left.2.55=354.8 \mu \mathrm{g} / \mathrm{mL}\right)$. Those findings are clarified again by Han et al. [35], triterpene glycosides (glycosides 1-3) isolated by sea cucumber showed the cytotoxicity activities oh the tumor cell of P-388, A549, MKN-28, HCT116, and MCF7 with concentration $\mathrm{IC}_{50} 0.93-2.60 \mu \mathrm{mol} / \mathrm{L}$. In our research used to concentration $0.5-4 \mu \mathrm{g} / \mathrm{ml}$.. Based on the data obtained from this study, the cytotoxic activity of the glycosides of $H$. atra is highly sensitive to the Sp-C1 cell of tongue carcinoma.

\section{Expression of Bcl-2 and Fas proteins}

In general, the triterpene glycoside of $H$. atra has better than the potential for inducing the expression of Fas protein (active 71\%; moderate $10 \%$; and non-active $27 \%$ ). Meanwhile, Bcl-2 protein has active $59 \%$, moderate $14 \%$, and non-active $27 \%$. Both Fas and Bcl-2 are statistically significant $(\mathrm{p}<0.05)$ (Fig. 3). These results were shown that the triterpene glycoside of $H$. atra has immunogenically better that to Fas protein compared to Bcl-2 (Fig. 4). Zhao et al. [36] (2012) [31] reported in his research that the triterpene glycosides could be causing to decrease the expression of the Bcl-2 protein and Mcl-1 and also to increase the sub-G0/G1 population of apoptotic cells and expression of Bax protein. These are a role in the expression of inhibitor cyclindependent kinase, p21, and the last to activated caspases 3, 7, and 9 [27].

The result of the study identified that triterpene glycosides of $H$. atra can trigger the expression of $\mathrm{Bcl}-2$ and Fas protein. Its active component

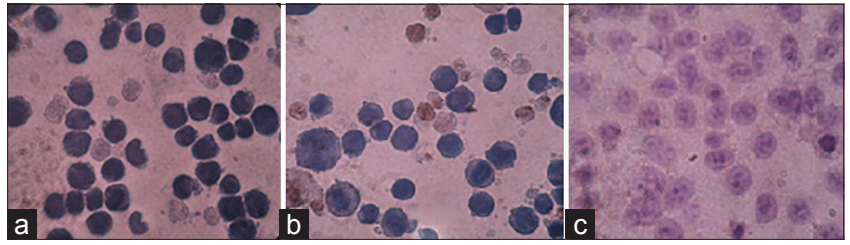

Fig. 4: Profile immunocytochemistry of Bcl-2 (a), Fas (b), and negative control (c)

possibility can be used to early detect the tumor of tongue carcinoma. Aminin et al. [19] give expression which the holothurian triterpene glycosides be a biology agent for cytostatics therapy.

Bcl-2 and Fas are the protein that mixed up with activated the tumor cell. Commonly, both expression Bcl- 2 and Fas proteins were facilitated by ligand (FasL) contained in the cell surface that roles to improve the cell cycle and to prevent the apoptosis. Fas protein resistance-pathway also to contribute the Bcl-2 protein through linked-phosphatase-1, and soluble Fas (sFas) mRNA [37]. Expression of Fas protein and its ligand FasL was detected on the 44 subjects (88\%) of the mount 50 subjects $(100 \%)[38]$.

\section{Apoptosis analyses}

Build on the study, triterpene glycoside has apoptosis effect on the SpC1 cell of tongue carcinoma $87 \%$ (strong) and 13\% (moderate) (Fig. 5), with indicator scale $0-5 \%$ (weak), 5-25\% (moderate), and $25-100 \%$ (strong), significant $(\mathrm{p}<0.05)$ and strong correlation $(\mathrm{r}=0.92)$. Yun et al. [39] suggested that this research has been the strongly correlated effect of triterpene glycoside to induce the apoptosis in a way inactivated the Fas protein and caspase-8, cleavage of Bid, mitochondrial damage, and caspase-3 activation [40]. Plati et al. [41] adduced that the apoptosis 
Table 1: Cytotoxicity assay of triterpene glycoside $H$. atra on the Sp-C1 cell

\begin{tabular}{lllllllll}
\hline Doses $(\boldsymbol{\mu g} / \mathbf{m l})$ & Average (OD) & SDV & Mortality $(\%)$ & Scale & Log10-Concen & Anti-Log & $\mathbf{p}$ & $\mathbf{R}$ \\
\hline 4 & 0.049 & 0.058 & 88 & Strong & 0.602 & 0.274 & $0.014(\mathrm{p}<0.05)$ \\
3.5 & 0.096 & 0.076 & 83 & Strong & 0.544 & 0.248 & \\
3 & 0.082 & 0.069 & 85 & Strong & 0.477 & 0.217 & \\
2.5 & 0.118 & 0.021 & 81 & Strong & 0.398 & 0.181 & \\
2 & 0.326 & 0.090 & 57 & Moderate & 0.301 & 0.137 & \\
1.5 & 0.356 & 0.072 & 54 & Moderate & 0.176 & 0.080 & \\
1 & 0.515 & 0.006 & 36 & Non-active & 0.000 & 0.000 & \\
0.5 & 0.745 & 0.118 & 10 & Non-active & -0.301 & -0.137 & \\
\hline
\end{tabular}

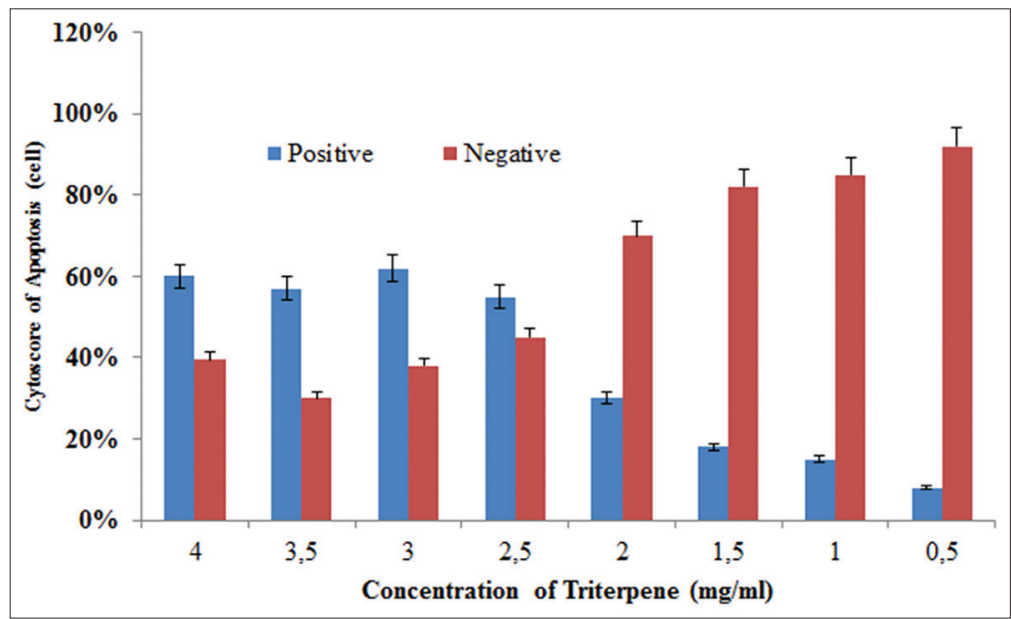

Fig. 5: Apoptosis frequency of Supri's-Clone 1 cell of tongue carcinoma after administrated by triterpene glycoside of Holothuria atra

is inducible undergo FasL, tumor necrosis factor, and TRAIL bind on the target receptor. Meanwhile, caspases, family protein Bcl-2 will be the programming of death naturally. Meanwhile, caspases, family protein Bcl- 2 will be the programming of death naturally in the regulation of immune response [36]. Furthermore, the flavonoid of plant herbal has to the prevention of cancer by inhibiting signal transduction enzymes, protein tyrosine kinase, protein kinase $\mathrm{C}$, and phosphoinositide 3-kinases. The signals are involved in the regulation of cell proliferation [42].

Sp-C1 cell that experienced apoptotic to expressed the Fas and its ligand on the tumor cell surface [Fig.6]. In the case of hepatocellular carcinoma, changing the structure of Fas protein was related to the expression of the Bcl-2 protein and reported to inhibit the apoptosis [12]. In this guided that shown triterpene glycoside can interfere with Bcl-2 and fast protein expressions, so as the tumor cell is not developed and the checkpoint phase will be back operated in the apoptosis occurrence [43].

\section{CONCLUSION}

Triterpene glycoside of $\mathrm{H}$. atra has been cytotoxicity effect on the Sp-C1 cell of tongue carcinoma, also inducible to expression the Bcl-2 dan Fas protein, at once to regulated the apoptosis of the Sp-C1 cell. Based on the result, triterpene glycoside of $H$. atra be possibility will be used as the active biology material to prevent the tumor metastatic of the tongue and applicable on the cancer whole body.

\section{ACKNOWLEDGMENTS}

Laboratory of integrated research, Universitas Gadjah Mada, Yogyakarta, Indonesia, was given $\mathrm{Sp}-\mathrm{C} 1$ cell. The best thank to the Sumatera Biota Laboratory, Andalas University, Padang, Indonesia had been facilitated preparation triterpene glycoside of $H$. atra.
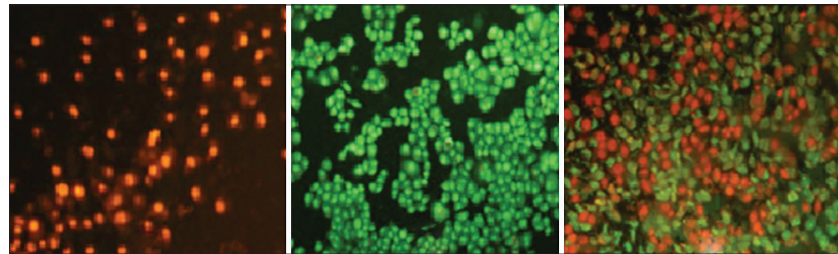

Fig. 6: Analyzed by double staining ethidium bromide acridine orange on the culture of the Supri's-Clone 1 cell, apoptosis cell (red), and non-apoptosis (green), magnified at $\times 40$. (a) Control positive, (b) control negative, (c) treatment

\section{AUTHOR'S CONTRIBUTIONS}

UA carried out the conception, cytotoxicity assay, immunocytochemistry assay, and apoptosis assay also drafted the manuscript with BAG and MHS. Whereas, SI, DH, AP, and NK have been given the research ideas and design of research and include the preparation of triterpene glycoside of Holothuria atra. Specifically, BAG has been arranged the manuscript, statistical analysis, and corresponding author. All of the authors were read and approved the final manuscript.

\section{CONFLICT OF INTEREST}

The authors declare that there is no conflict of interest.

\section{REFERENCES}

1. Warren TA, Panizza B, Porceddu SV, Gandhi M, Patel P, Wood M, et al. Outcomes after surgery and postoperative radiotherapy for perineural spread of head and neck cutaneous squamous cell carcinoma. Head Neck 2016;38:824-31.

2. Khan Z. An overview of oral cancer in Indian subcontinent and 
recommendations to decrease its incidence. Web Med Central Cancer 2012;3:WMC003626.

3. Huang SH, Perez-Ordonez B, Liu FF, Waldron J, Ringash J, Irish J, et al. A typical clinical behavior of p16-confirmed HPV-related oropharyngeal squamous cell carcinoma treated with radical radiotherapy. Int J Radiat Oncol Biol Phys 2012;82:276-83.

4. Feller L, Lemmer J. Oral squamous cell carcinoma: Epidemiology, clinical presentation, and treatment. J Cancer Ther 2012;3:263-8.

5. Zhang H, Dziegielewski PT, Biron VL, Szudek J, Al-Qahatani KH, O'Connell DA, et al. Survival outcomes of patients with advanced oral cavity squamous cell carcinoma treated with multimodal therapy: A multi-institutional analysis. J Otolaryngol Head Neck Surg 2013;42:1-8.

6. Bo JH, Park JH, Chung IS. Tumstatin induces apoptosis mediated by fas signaling pathways in oral squamous cell carcinoma SCC-VII cells. Onco Lett 2015;10:1016-22.

7. Hossain Z, Sugarawa T, Hirata T. Sphingoid bases from sea cucumber induce apoptosis in human hepatoma HepG2 cells through p-AKT and DR5. Oncol Rep 2013;29:1201-7.

8. Dahiya J, Marwaha RK, Dureja H. Therapies in cancer treatment: An overview minakshi gupta. Int J Pharm Pharm Sci 2015;7:1-9.

9. Gabrielli B, Brooks K, Pavey S. Defective cell cycle checkpoints as targets for anti-cancer therapies. Front Pharmacol 2012;3:1-6.

10. Fulda S. Targeting apoptosis for anticancer therapy. Semin Cancer Biol 2015;31:84-8

11. de Bruyn M, Bremer E, Helfrich W. Antibody-based fusion proteins to target death receptors in cancer. Cancer Lett 2013;332:175-83.

12. Qi F, Li A, Inagaki Y, Xu H, Wang D, Cui X, et al. Induction of apoptosis by cinobufacini preparation through mitochondria-and fas-mediated caspase-dependent pathways in human hepatocellular carcinoma cells. Food Chem Toxicol 2012;50:295-302.

13. Agbarya A. Ruimi N. Epelbaum R, Ben-Arye, E. Mahajna, J. Natural products as potential cancer therapy enhancers: A preclinical update. SAGE Open Med 2014;2:1-11.

14. Susanti S, Iwasaki H, Itokazu Y, Nago M, Taira N, Saitoh S, et al. Tumor-specific cytotoxicity of arctigenin isolated from herbal plant Arctium lappa L. J Nat Med 2012;66:614-21.

15. Liu C, Dai L, Liu Y, Rong L, Dou D, Sun Y, et al. Antiproliferative activity of triterpene glycoside nutrient from monk fruit in colorectal cancer and throat cancer. Nutrients 2016;8:360.

16. Stonik, VA, Fedorov, SN. Marine low molecular weight natural products potential cancer preventive compounds. Mar Drugs 2014;12:636-71.

17. Januar HI, Nursid M, Chasanah E. Cytotoxic saturated fatty acid from the Indonesian sea cucumber Holothuria sp. Squalene Bull Mar Fish Postharvest Biotech 2014;9:11-5.

18. Yano A, Abe A, Aizawa F, Yamada H, Minami K, Matsui M, et al. The effect of eating sea cucumber jelly on Candida load in the oral cavity of elderly individuals in a nursing home. Mar Drugs 2013;11:4993-5007.

19. Aminin DL, Menchinskaya ES, Pislyagin EA, Silchenko AS, Avilov SA, Kalinin VI. Sea cucumber triterpene glycosides as anticancer agents. Mar Drugs 2015;13:1202-23.

20. Yang J, Wang Y, Zhang R, Jiang T, Lv Z. Determination of the triterpene glycosides in sea cucumbers by liquid chromatography with evaporative light scattering and mass spectrometry detection. J Sep Sci 2015;38:1117-22.

21. Negi JS, Singh P, Pant GJ, Rawat M. High-performance liquid chromatography analysis of plant saponins: An update 2005-2010. Pharmacog Rev 2011;5:155.

22. Haridas R, Manorama S, Thekkan S. In-vitro cytotoxicity activity of Malaxis rheedii SW methanol extract against Hela cell line and Mcf-7 cell line. Asian J Pharm Clin Res 2016;9;244-6.

23. Li W, Zhou J, Xu Y. Study of the in vitro cytotoxicity testing of medical devices. Biomed Rep 2015;3:617-20.

24. Yuliani SH, Anggraeni CD, Sekarjati W, Panjalu A, Istyastono EP, Setiawati A. Cytotoxic activity of Anredera cordifolia leaf extract on hela cervical cancer cells through P53-independent pathway. Asian J Pharm Clin Res 2015;8:328-31.

25. Liang CZ, Zhang JK, Shi Z, Liu B, Shen CQ, Tao HM. Matrine induces caspase-dependent apoptosis in human osteosarcoma cells in vitro and in vivo through the upregulation of Bax and Fas/FasL and downregulation of Bcl-2. Cancer Chemother Pharmacol 2012;69:317-31

26. Grobholz R, Zentgraf H, Köhrmann KU, Bleyl U. Bax, Bcl-2, Fas and Fas-L antigen expression in human seminoma: Correlation with the apoptotic index. Apmis 2002;110:724-32.

27. Li X, Roginsky AB, Ding XZ, Woodward C, Collin P, Newman RA, et al. Review of the apoptosis pathways in pancreatic cancer and the antiapoptotic effects of the novel sea cucumber compound, frondoside A. Ann N Y Acad Sci 2008;1138:181-98.

28. Batra P, Sharma AK. Anti-cancer potential of flavonoids: Recent trends and future perspective. Biotechnology 2013;3:439-59.

29. Chudzik M, Korzonek-Szlacheta I, Król W. Triterpenes as potentially cytotoxic compounds. Molecules 2015;20:1610-25.

30. Bishayee A, Ahmed S, Brankov N, Perloff M. Triterpenoids as potential agents for the chemoprevention and therapy of breast cancer. Front Biosci (Landmark Ed) 2011;16:980-96.

31. Itharat A, Houghton PJ, Eno-Amooquaye E, Burke PJ, Sampson JH, Raman A. In vitro cytotoxic activity of Thai medicinal plants used traditionally to treat cancer. J Ethnopharmacol 2004;90:33-8.

32. Molyneux P. The use of the stable free radical diphenylpicrylhydrazyl (DPPH) for estimating antioxidant activity. Songklanakarin J Sci Technol 2004;26:211-9.

33. Fajarningsih N, Nursid M, Wikanta T, Marraskuranto E. Bioactivity of Turbinaria decurrens extract as the anti-tumor and its effect on the lymphocyte proliferation. J Pascapanen Bioteknol Sea Fis 2008;3:1-7.

34. Jangwan JS, Singh R. In the vitro cytotoxic activity of triterpene isolated from bark of Randia dumetorum Lamk. J Curr Chem Pharm Sci 2014;4:1-9.

35. Han H, Li L, Yi YH, Wang XH, Pan MX. Triterpene glycosides from sea cucumber holothuria scabra with cytotoxic activity. Chin Herb Med 2012;4:183-8

36. Zhao $\mathrm{Q}$, Xue $\mathrm{Y}$, Wang JF, Li $\mathrm{H}$, Long $\mathrm{TT}$, Li Z, et al. In vitro and in vivo anti-tumour activities of echinoside $\mathrm{A}$ and ds-echinoside $\mathrm{A}$ from Pearsonothuria graeffei. J Sci Food Agric 2012;92:965-74.

37. Lee SH, Shin MS, Lee JY, Park WS, Kim SY, Jang JJ, et al. In vivo expression of soluble fas and FAP-1: Possible mechanisms of fas resistance in human hepatoblastomas. J Pathol 1999;188:207-12.

38. Lee SH, Shin MS, Lee HS, Bae JH, Lee HK, Kim SY, et al. Expression of fas and fas-related molecules in human hepatocellular carcinoma. Hum Pathol 2001;32:250-6.

39. Yun SH, Park ES, Shin SW, Na YW, Han JY, Jeong JS, et al. Stichoposide C induces apoptosis through the generation of ceramide in leukemia and colorectal cancer cells and shows in vivo antitumor activity. Clin Cancer Res 2012;18:5934-48.

40. Tschopp J, Thome M, Hofmann K, Meinl E. The fight of viruses against apoptosis. Curr Opin Genet Dev 1998;8:82-7.

41. Plati J, Bucur O, Khosravi-Far R. Apoptotic cell signaling in cancer progression and therapy. Integr Biol (Camb) 2011;3:279-96.

42. Thampi N, Shalini JV. Anti-proliferative and apoptotic activities of Syzygium samarangense (wax apple) fruits extract against human A549 lung cancer cell lines. Int J Pharm Pharm Sci 2015;7:361-5.

43. Foroutan B, Razavianzadeh N, Anderson D. Overcoming chemoresistance in non-hodgkin lymphoma preliminary studies of apoptosis and necrosis by P-glycoprotein reversal agents. Int J Pharm Pharm Sci 2015;7:382-8. 